PESHAWAR JOURNAL OF PSYCHOLOGY AND BEHAVIORAL SCIENCES, 2018, VOL. 4, NO. 1, 15-31

\title{
Gender Differences in Social Support, Loneliness, and Isolation among Old Age Citizens
}

\author{
Salma Naz Gul ${ }^{1}$, Rabia Chishti ${ }^{2}$ \\ University of Peshawar \\ and \\ Maher Bano ${ }^{3}$ \\ Preston University, Peshawar
}

The present paper attempted to explore the impact of gender on social support, social isolation and loneliness (social and emotional) among senior citizens. In order to assess the study constructs 6-Item (short) De Jong Gierveld Loneliness Scale (1985), 6-item (short) scale developed by Hawthorne (2006) and, Social Support Scale developed by Malik (2002) were used. Standardized back translation procedure was used for the translation of the measures into Urdu. Purposive convenient sampling technique was used to draw the sample of 500 senior citizens from both urban and rural areas of the various districts of the Khyber Pakhtunkhwa province of Pakistan. The age of the participants ranged between 60 to 90 years $(M=67.59, S D$ $=7.54$ ). -test analysis revealed significant gender differences on social support and its sub constructs. Moreover results demonstrated non-significant gender differences for isolation and loneliness.

Keywords: gender, social support, social loneliness, emotional loneliness, social isolation

\footnotetext{
${ }^{1}$ Lecturer, College of Home Economics, University of Peshawar

${ }^{2}$ Lecturer, College of Home Economics, University of Peshawar

${ }^{3}$ Professor, Department of Psychology, Preston University Kohat, Khyber Pakhtunkhwa

ISSN 2415-6779 EISSN 2518-4474

https://doi.org/10.32879/picp.2018.4.1.15

www.pjpbsicp.com
} 
Aging is a natural phenomenon and human life cycle is divided into different ages groups. Every age of human life has its own beauty but of all the ages, old age is usually considered as the scariest period in human life cycle. Grey hair where stand for experience and lifelong efforts also marks decline in physical and mental strength. It is time of a person's life where he starts depending on others for his needs.

Old age is composed of the ages nearing or surpassing the life expectancy of human beings, and thus the end of the human life cycle. There are different terms used for old age but general definition remains the same. Definition and period of old age may differ from person to person or region to region affected by certain factors of environment, financial status, social and religious inclinations, family background etc. but in general after 60 years old age is considered to be started. It is usually defined as the age that is heading towards end of life cycle of humans (Golden et al, 2009).

According to American Psychological Association, (2009), a few soft terms used for elder people across the world i.e. common terminology used for old age is old people. In American expression word "seniors" is used for old age. In Britain and also in some parts of America "senior citizens" is used for people in their old age. According to social sciences, word used for people in their old age are called "senior citizens". They are also termed elders or elderly people in many known cultures of the world. Known trademarks associated with old age are quite inadequate prospects of healing and vulnerability to different diseases, and physical and internal weaknesses as compared to young people (Litwin H, Landau R, 2000).

In addition to explanation of these scientific terms associated with old age and its problems, there are certain issues that old people experience socially which in turn make old age more or less vulnerable depending on the severity of the issues. Old age comes after youth and after living middle age that is usually taken as decay of mental and physical strength. (Oxford English Dictionary, 2013).Although, old age is considered different and varies from region to region and in different time frame as well. Hence it could be concluded that social issues like position in family, difficulty in getting jobs, retirement and physical condition determines vulnerability of old age as compared to natural and biological phase of life (http://www.bbc.co.uk/news/uk-politics-24572231).

Old people are often embraced with many issues that results from their age: With decline in physical strength, one is socially not active as that of before and in long run feels segregated and isolated. They are more 
prone to disease, syndromes, and sickness than younger adults, and have limited regenerative abilities to combat with these problems. The organic process of ageing is called senescence, which is natural process of getting old, whereas the terms used for medical study for ageing are gerontology and geriatrics that explain troublesome effects that various diseases have on old people. (Allyn \& Bacon, 2010).

Theory "Eight stages of Life" of Erikson (1963) establishes that individuality and characteristics of humans are made and modified in eight stages starting from birth of a person and goes along with ageing process till end of life. Erikson finds out old age as phase of life where there is integrity vs despair. People in old age think back on their past life and people with no achievements have compunction on their past life and this feeling of regret brings disappointment to the person. Such an individual is prone to distress and may feel frustrated. People who are satisfied with their achievements feel good that imparts them feeling of integrity (Carver \& Scheir, 2000; Erikson, 1963, 1968).

\section{Loneliness, social isolation and social support}

Loneliness frequently means trouble connected to an absence of near societal relations, especially those that encourage integration and passionate closeness (Green et al., 2001; Rook, 1984). These components speak to an obnoxious condition of being, promoting a low quality of life and harmful wellbeing results. The study of Dykstra, (2009), found that loneliness is an undesirable personal feeling although social isolation is the objective state of not having ties with other individuals. Scharf T (2011), affirms this, in one of his investigations that loneliness could be seen as a constant state, being desolate normally speaks to the persistence of longlasting troublesome associations with relatives and constrained associations with companions and neighbors, or it can be connected to the effect of specific life occasions or misfortunes associated with age (e.g. Widowhood). Moreover Forbes in his studies in (1996), identifies both social and emotional isolation in experience of isolation and both were regarded as unfavorable by him.

According to Luanaigh and Lawlor, (2008); social isolation and loneliness negatively effect one's perception about their health and welfare. However study recommends that ways leading to loneliness differ among old age individuals. Some senior citizens live their whole life lonely, and others turn out to be lonely with age, though still others turn out to be less lonely in old age (Dykstra et al., 2005; Victor et al., 2005).

PESHAWAR JOURNAL OF PSYCHOLOGY AND BEHAVIORAL SCIENCES, 2018, VOL. 4, NO. 1, 15-31 
Social support is an essential element to cope with difficulties of senior citizens. Provision of social support is important for senior citizens as it aids in reducing the impacts of social isolation and loneliness. Longitudinal investigations by Bassuk, et al. (1999), revealed that those old age individuals who don't have connections of societal group have greater chances of being socially isolated than those senior citizens who have proper societal group connections.

\section{Causes of social isolation and loneliness among old aged people}

The causes of loneliness and social isolation can be numerous, for example, living alone, marital status/widowhood/ divorce, absence of children, low education, poverty, illness, retirement; and so forth.

The study of Victor et al, (2005); Cann and Jopling, (2011), explains that loneliness start slowly in old age and in some cases, loneliness occurs through a particular life incident, particularly one related with some shortfall, like e.g. retirement, or grief etc. The threats of loneliness rises when an individual has more responsibilities in their lives. These life moves have greater probability to occur at old age because the risk of loneliness and isolation are greater for senior citizens. Schnittger et al, (2012), further highlights that because of the death or disease of earlier relations societal linkages may possibly reduce in extent, or due to their own poor health old age individuals may be incapable to take part in formerly delighted events. Furthermore ill health, mental and physical deficiency are also the reasons for loneliness and isolation denoted by Victor et al, (2005).

\section{Gender and old age}

While observing gender, Pechtel and Pizzagalli, (2010) explains the gender differences due to different developmental lines for males and females. It was stated that early life experiences may indicate various consequences for males and females individually. According to Kimmel, (2004), that over eras, variations among male and female individualities usually altered through historical, traditional, and normative settings. Customary the roles of old age females are described as that of linkage and families guardians (Dykstra \& Fokkema, 2007; Rosenthal, 1985), while the role of males are more related with the provisions of goods to their families.(Thorsen, 1998). Females likewise appear to be more eager to discover, confess, and describe her emotional state such as loneliness 
(Barstad, 2004; Nolen-Hoeksema \& Rusting, 2000; Pinquart, 2003; Pinquart\& Sorensen, 2001).

According to some research reports, females have greater occurrence of loneliness than males Savikko, Routasalo, Tilvis, Strandberg, \&Pitkala, 2005; Tornstam, Rydell, Vik, \& Oberg, 2010; Victor $\&$ Yang, 2012). this has been clarified through the more occurrence of widowhood in females (Dahlberg et al., 2013; Drennan et al., 2008; Victor, Scambler, Marston, Bond, \& Bowling, 2006). The study of Savikko et al., (2005), also confirmed these findings that women are more related with loneliness than men, Thorsen, (1990); Tornstam, (1992), further added that this relates only to those male and females who are married (e.g. Aartsen \& Jylha, 2011; Cohen-Mansfield et al., 2009; Dykstra et al., 2005; O’Luanaigh\& Lawlor, 2008; Pinquart \& Sorensen, 2001),

Jylha, (2004); Victor, Scambler, et al., (2005), their research regarding gender observed minor difference or no differences at all, rather to study loneliness the researchers found these elements significant such as marital status, age, physical well-being, and living provisions .

According to Perlman, (2004), that females consider themselves more lonely than males while reliable tests for measuring isolation and loneliness propose minimum differences between males and females. Routasalo and Pitkala, (2003), stated in their study that former investigations regarding gender differences formed inconsistent results about the relation among gender and loneliness. Though, study observing on social loneliness and emotional loneliness independently have observed that males have more social loneliness and less emotional loneliness than females. (Dykstra \& Fokkema, 2007; Dykstra \& Gierveld, 2004; Green et al., 2001).

Isolation and loneliness happens at any phase of lifetime of a person but it become a complex problem for senior citizens. Isolation and old age is not necessarily responsible for each other but still both have close relationship

To have more vivid comprehension there is still need that continuous exploration ought to investigate certain mental and social issues connected with senior citizens. It is along these lines, present study is a practical attempt to observe the association between social support, social isolation and loneliness in old age individuals. Furthermore, it also aims in-depth exploration of demographic issues relevant to the subject and to investigate the mean gender difference on social support, social isolation, and loneliness among older people 
The purpose of the present study paper is to explore the impact of gender on social support, social isolation and loneliness (social and emotional) among senior citizens

\section{Hypotheses}

To investigate the mean gender difference on social support, social isolation, and loneliness among older people following hypotheses were formulated

- Old age males will score low on social support as compare to females.

- Old age females will score higher on loneliness and social isolation as compare to males

\section{Method}

\section{Sample}

The sample of the present study included 500 older people $(N=)$ which comprised of males $(n=250)$ and females $(n=250)$. According to Erickson's "Psycho Social theory" the base line of old age is around 60 years. The sample was extracted from both Urban and Rural areas of Peshawar through purposive convenient sampling technique and were also catalogued on the bases of socio economic status.

\section{Instruments}

A number of instruments were used to measure the appropriate constructs of the study which are as follow:

\section{Social Support Scale (SSS).}

The SSS is 51 items scale developed by Malik (2002) which is anchored on 4-point Likert type rating. This scale comprised of five subscales such as Informational Support, Tangible Aid, Emotional Support, Esteem Support, and Social Network Support. SSS has a highly significant Pearson r-value for test-retest reliability i.e .85 whereas the alpha coefficient for SSS is .94.

\section{De Jong Gierveld Loneliness Scale (1985).}

A6-Item short De Jong Gierveld Loneliness Scale is also used to measure the other variable. It is anchored on Liker type response format 
with a Cronbach's alpha as reported by authors as .71 for 6-Item scale and .68 and .69 for Emotional and Social Loneliness subscale respectively.

\section{Friendship Scale (2006).}

Friendship Scaleis a Likert type 6-item scale developed by Hawthorne (2006) and was used to evaluate the level of social isolation. All the Items were reverse scored to measure the construct accordingly. Cronbach alpha on sample of 829 senior citizens was demonstrated excellent $(\alpha=.83)$.

\section{Procedure}

The study was carried out into two steps. In first step original scales for social isolation and loneliness was translated in to Urdu. Back translation method was carried out through standard translation procedure.

The second step was carried out to meet the objectives of the study. For this purpose, sample of the study i.e. senior citizens were selected both from urban and rural areas of different districts of Khyber Pakhtunkhwa. First, the participants were brief about the objectives of the study, informed consent was taken and confidentiality of the participants was ensured. After giving required instructions (written as well as oral) the scales of the study were given to the participants.

\section{Results}

Table 1

Demographic Characteristics of the Sample of Main Study $(n=500)$

\begin{tabular}{lccc}
\hline Variables & Male $f(\%)$ & Female $\mathrm{f}(\%)$ & Total $f(\%)$ \\
\hline Gender & $250(50)$ & $250(50)$ & $500(100)$ \\
Age & & & \\
$60-69$ Years & $142(28)$ & $199(40)$ & $341(68)$ \\
$70-79$ Years & $83(17)$ & $42(8)$ & $102(25)$ \\
$80-89$ Years & $25(5)$ & $9(2)$ & $49(7)$ \\
90 and above & - & - & $8(.01)$ \\
Educational Level & & & \\
Illiterate & $81(16)$ & $90(18)$ & $171(34)$ \\
Primary & $14(3)$ & $14(3)$ & $28(6)$
\end{tabular}

PESHAWAR JOURNAL OF PSYCHOLOGY AND BEHAVIORAL SCIENCES, 2018, VOL. 4, NO. 1, 15-31 
Middle

Matriculate

Intermediate

Graduate

Postgraduate

Socio Economic Status

High Class

Middle Class

Lower Class

Marital Status

Married

Unmarried

Widow(ed)

Divorced

No of Family Members

1-5 family

members

6-10

11-15

16-20

21 and above

Not Reported

Residential Status

Urban

Rural
$23(5)$

$38(8)$

19 (4)

$38(8)$

$28(5)$

$27(5)$

$111(22)$

$112(22)$

237 (47.)

$5(1)$

$1(0)$

7 (1)

$26(63.4)$

$68(66.7)$

$41(59.4)$

$23(53.5)$

07(53.8)

85 (36.6)

$176(35)$

$74(15)$
$30(6) \quad 53(11)$

$72(14) \quad 110(22)$

$24(5) \quad 43(9)$

$10(2) \quad 48(10)$

19 (4) $\quad 47(9)$

$29(6) \quad 56(11)$

$86(17) \quad 197(40)$

$135(27) \quad 247(49)$

$171(34) \quad 408(81)$

$17(4) \quad 22(5)$

$6(1)$

7 (1)

$56(11)$

$63(12)$

$15(36.6) \quad 41(15.3)$

$34(33.3) \quad 102(38.1)$

$28(40.6) \quad 69(25.7)$

$20(46.5) \quad 43(16)$

$06(46.2) \quad 13(4.9)$

$147(63.4) \quad 232(46.4)$

$192(38) \quad 368(73)$

$58(12) \quad 132(28)$

Table 1 illustrates frequency and percentages of the demographic characteristics of the sample of the study with respect to gender, age, educational level, socio economic status, marital status, number of family members, and residential status. Frequency and percentage of males and females in relation to each category have been described. The age range of 
the participants were $28 \%$ males and $40 \%$ females were within $60 \_70$ years whereas within the range $71 \_80$ years $17 \%$ were males and $8 \%$ were females, and among the range $81 \_90$ years 5\% were males and 2\% were females. The educational level of males were, $16 \%$ were illiterate and $33 \%$ were literate among females $18 \%$ were illiterate and $34 \%$ were literate . 5\% of males and $6 \%$ of females were of high socio economic status, whereas $22 \%$ males and $17 \%$ females were of middle class and $22 \%$ males and $27 \%$ females were of low socio economic status. Out of 500 participants, 250 were male and 250 were female, $47 \%$ males were married, whereas $34 \%$ females were married. Response rate regarding number of family members was $53.6 \%(\mathrm{n}=268), 15.3 \%$ belonged to small family who had $1-5$ number of family members $63.4 \%$ were males and $15 \%$ were females, $66.7 \%$ males and $33.3 \%$ females had 6-10 number of family members,59.4\% males and $40.6 \%$ females were from large family who had 11-15 number of family members, $53.5 \%$ of males and $46.5 \%$ of females had 15-20 number of family members, $53.8 \%$ males and $46.2 \%$ females belonged to extended family who had 21 and above number of family members.35\% males and $38 \%$ females belonged to Urban area whereas $15 \%$ males and $12 \%$ females belonged to Rural area.

Table 2

Descriptive Statistics and Alpha Reliabilities for all the Study Variables ( $N$ $=500)$

\begin{tabular}{|c|c|c|c|c|c|c|}
\hline & \multirow[b]{2}{*}{$M$} & \multirow[b]{2}{*}{$S D$} & \multirow[b]{2}{*}{$A$} & \multicolumn{2}{|c|}{ Range } & \multirow[b]{2}{*}{ Skewness } \\
\hline & & & & Potential & Actual & \\
\hline \multicolumn{7}{|c|}{ Sub Scales of Social Support } \\
\hline $\begin{array}{l}\text { Instrumental } \\
\text { Support }\end{array}$ & 8.57 & 2.59 & .70 & $0-3$ & $.56-.85$ & 1.56 \\
\hline Tangible Aid & 9.07 & 2.64 & .70 & $0-3$ & $.56-.70$ & 1.25 \\
\hline $\begin{array}{l}\text { Emotional } \\
\text { Support }\end{array}$ & 6.37 & 1.91 & .86 & $0-3$ & $.54-1.13$ & 1.45 \\
\hline $\begin{array}{l}\text { Esteem } \\
\text { Support }\end{array}$ & 19.94 & 5.58 & .83 & $0-3$ & $.62-.77$ & 1.87 \\
\hline $\begin{array}{l}\text { Social } \\
\text { Network }\end{array}$ & 24.73 & 6.64 & .86 & $0-3$ & $.48-79$ & 1.34 \\
\hline Total SS & 92.08 & 23.95 & .96 & $0-3$ & $.48-1.13$ & 1.76 \\
\hline \multicolumn{7}{|c|}{ Subscales of Loneliness } \\
\hline $\begin{array}{l}\text { Emotional } \\
\text { Loneliness }\end{array}$ & 6.37 & 1.91 & .65 & $0-4$ & $.64-.72$ & .87 \\
\hline
\end{tabular}

PESHAWAR JOURNAL OF PSYCHOLOGY AND BEHAVIORAL SCIENCES, 2018, VOL. 4, NO. 1, 15-31 


\begin{tabular}{ccccccc}
\hline $\begin{array}{c}\text { Social } \\
\text { Loneliness } \\
\text { Social }\end{array}$ & 5.29 & 1.84 & .60 & $0-4$ & $.63-.70$ & .67 \\
$\begin{array}{c}\text { Isolation } \\
\text { Total }\end{array}$ & 13.76 & 4.36 & .62 & $0-4$ & $1.30-2.22$ & 1.19 \\
$\begin{array}{c}\text { Loneliness } \\
\text { Note. } S S=\text { social support. }\end{array}$ & 11.66 & 2.95 & .64 & $0-4$ & $.62-.72$ & 1.25 \\
\hline
\end{tabular}

Table 2 demonstrates that alpha reliability coefficients for the scales used in present study ranged between .60 for social loneliness to .96 for social support total scales. This indicates that reliabilities are found to be satisfactory for various scales of the study. Table 2 also displays descriptive data and response ranges of scales being used for the sample of 500 senior citizens.

Table 3

Mean, Standard Deviation and t-Values of Study Variables among Males and Females $(N=500)$

\begin{tabular}{|c|c|c|c|c|c|c|c|c|}
\hline \multirow[t]{2}{*}{ Variables } & \multicolumn{2}{|c|}{$\begin{array}{l}\text { Male } \\
(n=250)\end{array}$} & \multicolumn{2}{|c|}{$\begin{array}{l}\text { Female } \\
(n=250)\end{array}$} & \multirow[b]{2}{*}{$t(498)$} & \multicolumn{2}{|c|}{$95 \% C I$} & \multirow{2}{*}{$\begin{array}{c}\text { Cohen's } \\
\quad d\end{array}$} \\
\hline & $M$ & $S D$ & $M$ & $S D$ & & $L L$ & $U L$ & \\
\hline IS & 8.30 & 2.69 & 8.84 & 2.67 & $2.27 *$ & -1.02 & -.07 & .07 \\
\hline TA & 8.54 & 2.57 & 9.67 & 2.61 & $4.54 * * *$ & -1.51 & -.60 & .12 \\
\hline EmoS & 23.18 & 6.88 & 25.04 & 7.05 & $3.00 * * *$ & -3.09 & -.65 &. .17 \\
\hline EstS & 18.90 & 5.58 & 20.98 & 5.29 & $4.24 * * *$ & -3.04 & -1.11 & .17 \\
\hline SNW & 23.68 & 6.47 & 25.77 & 6.65 & $3.65 * * *$ & -3.25 & -.94 & .12 \\
\hline TSS & 87.97 & 23.52 & 96.19 & 23.72 & $3.89 * * *$ & -12.37 & -4.07 & .14 \\
\hline SL & 5.20 & 1.86 & 5.37 & 1.83 & 1.01 & -.49 & .16 & .02 \\
\hline EL & 6.27 & 1.86 & 6.47 & 1.95 & 1.17 & -.54 & .14 & .03 \\
\hline $\begin{array}{l}\text { Loneli } \\
\text { ness }\end{array}$ & 11.47 & 2.70 & 11.84 & 3.18 & 1.39 & -.87 & .15 & 01 \\
\hline SI & 13.46 & 4.50 & 14.07 & 4.24 & 1.57 & -1.38 & .16 & .02 \\
\hline
\end{tabular}

Table 3 shows the mean, standard deviation and $t$ values for male and female senior citizens on study variables. Findings indicate significant mean differences on informational support $\{t(498)=2.27, p<.005\}$, tangible aid $\{t(498)=2.61, p<.001\}$, emotional social support $\{t(498)=$ $3.00, p<.001\}$, esteem social support $\{t(498)=4.24, p<.001\}$, social network support $\{t(498)=3.65, p<.001\}$, and total social support $\{t$ $(498)=3.89, p<.001\}$, where female scored higher on overall social 
support. Results also indicated non-significant mean differences on social loneliness, emotional loneliness, overall loneliness and social isolation.

\section{Discussion}

The finding of the study suggested a significance difference between male and female participants on their mean scores on informational support, tangible aid, emotional support, esteem social support, and social network support, where female scored higher on overall social support.

A logical explanation may be that females are given more respect in Pakistani society and all their needs are generally assumed to be fulfilled by the male family members. Secondly females are preferred in various situations and they have more opportunities to develop their interpersonal skill within family and with their peers. Therefore, they are supposed to achieve more social support as compared to their male counterpart.

Findings of Grundy (2006) support our argument who found that that females' interpersonal links are more solid and durable as compare to males. According to the study of Khalid Ahmad (2011) $20.5 \%$ females contrasted with $10.4 \%$ males stated that they mostly share their issues and stresses with their daughters. So it is comprehensible that old age women feel happy in sharing their issues with their family members and and receive higher social support from both male and female members. Though, mothers also depend on their male offspring for emotive care. Very limited participant of the study stated that companions and people residing near to their homes providing care and share their issues and stresses. Generally, close relatives and family members appear to be the imperative wellspring of providing care and share their difficulties and troubles.

Earlier researches further approve our results like one interesting finding of Boneva, Kraut and Frohlich, (2001), that women use telephone more frequently than men, and generally women uses telephone for

unimportant discussions and for expressing their feelings instead the researcher specifies that men call on telephone only for purpose. According to the studies of Antonucci and Akiyama, (1987), Barstad, (2004), Lowenthal and Haven, (1968) because of the customary age distinctions among husband and wife (husbands being elder than their wives), females have little chances of getting second marriage. The chances of husband death are high, though males have greater chances to live with their wives 
in their old age. Still, usually females have more societal links and have dear companion than males.

The results of the current study indicated non-significant gender differences in the mean scores of social loneliness, emotional loneliness, overall loneliness and social isolation.

A quite logical and plausible explanation is that the sample of present study was composed of older individuals and in Pakistani society both males and females experience the social isolation and loneliness with high pace. Their children and other relatives do not spend much time with them and rarely share their feelings of loneliness. It is therefore gender difference on social isolation and loneliness are not expected.

Previous literature regarding gender difference on loneliness and social isolation yields mixed findings. Foe example Jylha, (2004); Victor, Scambler, et al., (2005) explored that there were slight gender difference or no differences at all on loneliness, the researchers found these factors important such as marital status, age, physical well-being, and living provisions. On the other hand Perlman, (2004) found that females consider their selves more lonely than males while reliable tests for measuring isolation and loneliness propose minimum differences between males and females. Routasalo and Pitkala, (2003), also endorsed that former investigations regarding gender differences formed inconsistent results about the relation among gender and loneliness.

\section{Summary}

It is revealed from the finding of the study that there exists a a significance difference between males and females on their availability of informational, tangible and emotional support, and females and on average scored higher on overall social support. The results of the current study indicated non-significant gender differences in the mean scores of social loneliness, emotional loneliness, overall loneliness and social isolation. It is concluded that in our society especially rural areas elders are given importance and respect, as people in our society abide by certain traditions and customs. Moreover, people are concerned about their reputation in society. So here situation is quite in the favor of elder people. Elders are asked for suggestions and opinions in all affairs of family. And they have feeling of importance as they have a say in family. But even despite of this consideration towards them, there are certain factors that still can make them feel lonely. Measures should be taken in individual as well as 
collective capacity to combat negative feelings coming with old age. Old age, if treated well can prove institute for the society.

\section{Conclusion}

It is revealed from the finding of the study that there exists a a significance difference between males and females on their availability of informational, tangible and emotional support, and females and on average scored higher on overall social support. The results of the current study indicated non-significant gender differences in the mean scores of social loneliness, emotional loneliness, overall loneliness and social isolation. It is concluded that in our society especially rural areas elders are given importance and respect, as people in our society abide by certain traditions and customs. Moreover, people are concerned about their reputation in society. So here situation is quite in the favor of elder people. Elders are asked for suggestions and opinions in all affairs of family. And they have feeling of importance as they have a say in family. But even despite of this consideration towards them, there are certain factors that still can make them feel lonely. Measures should be taken in individual as well as collective capacity to combat negative feelings coming with old age. Old age, if treated well can prove institute for the society.

\section{Limitations}

Like most of the studies of social science there may be certain issues that contribute to the limitations of the present study. Most important is that the data was exclusively gathered through self-report inventories, which lacks the inclusion of multiple sources. Consequently, the relationships between our variables of study may have been inflated due to response bias.

\section{Suggestions}

Collection of data through multiple resources, for future researches, is suggested to enhance the validity and generalization of findings. Moreover, some valuable demographic variables were not exclusively controlled i.e., age, family system and cultural context. The recent research focused only on gender of senior citizens, it can also be considered as a limitation of the study.

Additional research needs to be carried out to study the further demographic information related to sample concerned. Longitudinal research is recommended to investigate this issue.

PESHAWAR JOURNAL OF PSYCHOLOGY AND BEHAVIORAL SCIENCES, 2018, VOL. 4, NO. 1, 15-31 
GUL, CHISHTI AND BANO

\section{References}

Ahmad, K. (2011). Senior citizens' social support and its effect on their everyday self-maintenance activities: Findings from the household survey of urban Lahore-Pakistan. South Asian Studies, 26(1), 37-52.

Allyn \& Bacon. (2010). Laura, E. Berk, Development Through the Lifespan, 607.

Antonucci, T. C., \& Akiyama, H. (1987). An examination of sex differences in social support among older men and women. Sex Roles 17, 737-749. doi: 10.1007/bf00287685.

Barstad, A. (2004). Fa isolerte, men mange erplagetavensomhet [Few are isolated, but many are tormented by loneliness]. Samfunnsspeilet, 18(5), 19-26.

Bassuk, S. S., Glass, T. A., \& Berkman, L. F. (1999) Social engagement and incident cognitive decline in community - dwelling elderly persons. Ann Intern Med. 131, 165-173.

Boneva, B., Kraut, R., \& Frohlich, D. (2001). Using E-mail for personal relationships: The difference gender makes in American. Behavioral Scientist, 45(3): 530-549.

Cann, P., \& Jopling, K. (2011). The challenge. Safeguarding the convoy: A call to action from the campaign to end loneliness, Oxfordshire: Age UK .

Carver, C. S., \& Scheir, M. F. (2000). Perspectives on personality. Needham Heights, MA.

Cohen-Mansfield, J., Shmotkin, D., \&Goldberg, S. (2009). Loneliness in old age: Longitudinal changes and their determinants in an Israeli sample. International Psychogeriatrics, 21(6),11601170.doi:10.1017/s1041610209990974.

Dahlberg, L., Andersson, L., McKee, K. J., \& Lennartsson, C. (2013). Predictors of loneliness among older women and men in Sweden: A national longitudinal study. Manuscript submitted for publication.

De Jong, G, J., \& Frans, K. (1985). The development of a rasch-type loneliness scale. Applied Psychological Measurement, 9, 289-99.

Drennan, J., Treacy, M., Butler, M., Byrne, A., Fealy, G., Frazer,K., \& Irving, K. (2008). The experience of social and emotional loneliness among older people in Ireland. Ageing and Society, 28, 1113-1132. doi:10.1017/s0144686_08007526.

Dykstra, P., \& Gierveld, J. (2004). Gender and marital-history differences in emotional and social loneliness among Dutch senior citizens. Canadian Journal on Aging, 23, 141-155.

PESHAWAR JOURNAL OF PSYCHOLOGY AND BEHAVIORAL SCIENCES, 2018, VOL. 4, NO. 1, 15-31 
Dykstra,P. A.,van Tilburg, T. G., \& De Jong Gierveld, J. (2005). Changes in older adult loneliness: Results from a seven-year longitudinal study. Research on Aging, 27(6), 725747.doi:10.1177/0164027505279712.

Dykstra, P. A., \& Fokkema, T. (2007). Social and emotional loneliness among divorced and married men and women: Comparing the deficit and cognitive perspectives. Basic and Applied Social Psychology, 29(1), 1-12.

Dykstra, P. A. (2009). Older adult loneliness: Myths and realities. European Journal of Ageing, 6(2), 91-100.

Erikson, E. H. (1963). Childhood and society. (2nd ed.). New York: Norton.

Erikson, E. H. (1968). Identity: Youth and crisis. New York: Norton.

Forbes, A. (1996). Loneliness. British Medical Journal, 313(7053),352354.

Golden, J., Conroy, RM., Bruce, I., et al (2009). Loneliness, social supports, mood and wellbeing in community-dwelling elderly, International Journal of Geriatric Psychiatry, 24, 694-700.

Green, L. R., Richardson, D. R., Schatten, E. C., Lago, T., \& Sorenson, J. G. (2001). Network correlates of social and emotional loneliness in young and senior citizens. Personality and Social Psychology Bulletin, 27, 281-298.

Grundy, E. (2006). "Gender and Healthy Aging." In Longer Life and Healthy Aging, Z. Yi, E. M. Crimmins, and Y. Carriere, eds. Pp. 173-199. Dordrecht, The Netherlands: Springer.

Hawthorne, G. (2006). Measuring social isolation in senior citizens: Development and initial validation of the friendship scale. Social Indicators Research, 77, 521-548.

Jylha, M. (2004).Old age and loneliness: Cross-sectional and longitudinal analyses in the Tampere longitudinal study on aging. Canadian Journal on Aging-Revue Canadienne Du Vieillissement, 23(2),157168.doi:10.1353/cja.2004.0023.

Kimmel, M. S. (2004). The gendered society (2nd ed.). Oxford: Oxford University Press.

Litwin, H., Landau, R. (2000).Social network type and social support among the old-old (Statistical Data Included). J Aging Stud 14, $213-$ 228. doi:10.1016/s0890-4065(00)80012-2 . 
Lowenthal, M. F., \& Haven, C. (1968). Interaction and adaptation: Intimacy as a critical variable. American Sociological Review, 33, $20-30$.

Luanaigh, C., \& Lawlor, BA. (2008). Loneliness and the health of older people, International Journal of Geriatric Psychiatry, 23, 12131221.

Malik, A. A. (2002). The study of social support as a determining factor in depressed and non-depressed as measure by indigenously developed social support scale. (Unpublished $\mathrm{PhD}$ thesis), University of Karachi, Karachi.

Nolen-Hoeksema, S., \& Rusting, C. L. (2000). Gender differences in wellbeing. In D. Kahneman, E. Diener \& N. Schwartz (Eds.), Wellbeing: The foundations of hedonic psychology. New York, NY: Russell Sage Foundation.

O'Luanaigh, C., \& Lawlor, B. A. (2008). Loneliness and the healthofolderpeople.InternationalJournalofGeriatricPsychiatry, 23(1 2),1213-1221.doi:10.1002/gps.2054.

Oxford English Dictionary. (2013). Oxford University Press. London.

Pechtel, P., \& Pizzagalli, D.A. (2010). Effects of early life stress on cognitive and affective function: An integrated review of human literature. Psychopharmacology, 214(1), 55-70.

Perlman, D. (2004). European and Canadian studies of loneliness among seniors. Canadian Journal on Aging La Revue can adienne du vieillissement, 23, 181-188.

Pinquart, M. (2003). Loneliness in married, widowed, divorced, and nevermarried senior citizens. Journal of Social and Personal Relationships, 20(1), 31-53.

Pinquart, M., \& Sorensen, S. (2001). Influences on loneliness in senior citizens: A meta-analysis. Basic and Applied Social Psychology, 23(4), 245-266.

Rosenthal, C. (1985). Kin keeping in the familial division of labor. Journal of Marriage and the Family, 47, 965-974.

Rook, K. (1984). Promoting social bonding: Strategies for helping the lonely and socially isolated. American Psychologist, 39, 1389-1407.

Routasalo,P.,\&Pitkala,K.H.(2003).Loneliness among older people. Reviews in Clinical Gerontology, 13, 303-311. doi:10.1017/S095925980400111X.

Savikko,N.,Routasalo,P.,Tilvis,R.S.,Strandberg,T.E.,\&Pitkala,K.H.(2005) .Predictorsandsubjectivecausesof loneliness in an aged population.

PESHAWAR JOURNAL OF PSYCHOLOGY AND BEHAVIORAL SCIENCES, 2018, VOL. 4, NO. 1, 15-31 
Archives of Gerontology and Geriatrics, 41 (3), 223-233. doi:10.1016/j.archger.2005.03.002.

Scharf, T. (2011). Loneliness: an urban perspective. Safeguarding the Convoy: a call to action from the Campaign to End Loneliness. Age UK Oxfordshire

Schnittger, RIB., Wherton, J., Prendergast, D., et al (2012). Risk factors and mediating pathways of loneliness and social support in community-dwelling senior citizens. Aging and Mental Health, 16(3), 335-346.

Thorsen, K. (1998). Kjønn, livsløpogalderdom [Gender, life course, and old age]. Bergen: Fagbok forlaget.

Thorsen, K. (1990). Ensomogalene, sammenoglykkelig? Ensomhetiulikealdersgrupper [Lonely and alone, together and happy? Loneliness in different age groups]. Oslo: Norskgerontologiskinstitutt. NGI-Rapport 2-1990.

Tornstam, L. (1992). Loneliness in marriage. Journal of Social and Personal Relationships, 9(2), 197-216.

Tornstam, L., Rydell, M., Vik, I., \& Oberg, E. (2010). Ensamheteni Sverige 1985-2008 [Loneliness in Sweden 1985-2008]. Uppsala: Sociologiskainstitutionen.

Victor, C. R. (1994). Old age in modern society. London: Chapman and Hall.

Victor, C. R., Scambler, S. J., Bowling, A., \& Bond, J. (2005). Prevalence of, and risk factors for, loneliness in later life: A survey of older people in Great Britain. Ageing \& Society, 25, 357-375.

Victor, C. R., Scambler, S. J., Marston, L., Bond, J., \& Bowling, A. (2006). Older people's experiences of loneliness in the UK: Does gender matter? Social Policy and Society, 5(01),27-38. doi:10.1017/S1474746405002733

Victor ,CD., et al (2005). The prevalence of and risk factors for loneliness in later life: A survey of older people in Great Britain. Ageing and Society, 25, 357-375. 